\title{
HIGH OCCURRENCE OF Entamoeba histolytica IN THE MUNICIPALITIES OF ARIQUEMES AND MONTE NEGRO, STATE OF RONDÔNIA, WESTERN AMAZONIA, BRAZIL
}

Rafael Vital dos SANTOS(1), Jucélia da Silva NUNES(2), Juliana Almeida de Souza Aranha CAMARGO(3), Eliana Maria Maurício da ROCHA(4), Gilberto FONTES(4) \& Luís Marcelo Aranha CAMARGO(3)

\begin{abstract}
SUMMARY
Introduction: Entamoeba histolytica infections were investigated in residents of the Ariquemes and Monte Negro municipalities in Rondônia State, Brazil. Methods: Stool samples of 216 individuals were processed by the spontaneous sedimentation method and analyzed by microscopy for detection of the E. histolytica/E. dispar complex, followed by the immunoassay method using an enzyme-linked immunosorbent assay-based kit for the E. histolytica stool antigen. Results: E. histolytica/E. dispar cysts were present in $61 \%(50 / 82)$ and $44 \%$ (59/134) of the samples from Ariquemes and Monte Negro respectively, with a significant difference in the occurrence of infection between the two populations $\left[p<0.05 ; \chi^{2}=5.2\right.$; odds ratio $\left.=2.0(1.1-3.6)\right]$. The E. histolytica antigen detection rate was $36.6 \%$ (30/82) for stool samples from Ariquemes, and 19.4\% (26/134) for stool taken from the residents of Monte Negro. The rate of the occurrence of amoebiasis was significantly higher in the population from Ariquemes $\left[p<0.05 ; \chi^{2}=7.8\right.$; odds ratio $=2.4(1.2-4.7)]$. Discussion: Due to the high occurrence of $E$. histolytica infected residents diagnosed in the region and the unavailability in local clinics of a test to distinguish between the two Entamoeba species, physicians should consider treating $E$. histolytica/E.dispar infections. Conclusion: The results indicate that $E$. histolytica infection is highly endemic in the studied areas.
\end{abstract}

KEYWORDS: Entamoeba histolytica; Amazônia; Rondônia; ELISA.

\section{INTRODUCTION}

Amoebiasis is an infection caused by the protozoan parasite Entamoeba histolytica, and remains a significant cause of morbidity and mortality which is responsible for up to 100,000 deaths worldwide each year ${ }^{9,15}$. However, there is an urgent need to review epidemiological data since they were obtained prior to the development of techniques that allow differentiation between the E. histolytica and E. dispar species.

According to what is established by the World Health Organization, the treatment of Entamoeba infections should be administered only in cases in which the presence of E. histolytica is confirmed ${ }^{15}$. Specific E. histolytica diagnosis is usually performed by enzyme-linked immunosorbent assay (ELISA) for antigen detection, or by polymerase chain reaction (PCR) to demonstrate $E$. histolytica-specific DNA in stool samples ${ }^{14}$. Unfortunately, these methods are not available in the local public health units of many developing countries.

In Brazil, the epidemiological distribution of amoebiasis remains elusive in many areas. The few surveys conducted in the country indicate that infection with E. histolytica is more common in the North and Northeast ${ }^{1,2,13}$ with prevalences ranging from $6.8 \%$ to $29.35 \%$, and is rarely found in the other regions of the country.
In the state of Rondônia in the northern region of the country, the status of E. histolytica infection is unknown. However, cases of diarrheal infections in children are frequent, with the presence of mixed infections associating several enteropathogenic agents ${ }^{10,11}$.

The aim of this study was to investigate the occurrence of amoebiasis by stool antigen detection in urban residents of Ariquemes and Monte Negro in the state of Rondônia, Western Amazonia, Brazil.

\section{MATERIAL AND METHODS}

Stool specimens and microscopic analysis: Stool samples were collected from randomly selected people from Ariquemes (63을 $27^{\prime}$ ' W;

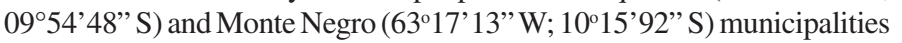
of Rondônia State (Fig. 1), in the period of June to October 2010. A single stool sample was collected from each person during home visits and the analysis was performed using the spontaneous sedimentation method $^{3,7}$. Identification of the parasites was carried out by examination of the sediment, stained with lugol, under light microscopy (400X). Fecal examination was used as a primary screening test for protozoa infections.

Enzyme-linked immunosorbent assay (ELISA) to antigen detection:

(1) Instituto de Ciências Biológicas e da Saúde, Universidade Federal de Alagoas, Maceió, AL, Brazil.

(2) Faculdade de Ciências Biomédicas de Cacoal, Cacoal, RO, Brazil.

(3) Instituto de Ciências Biomédicas 5, Universidade de São Paulo, Monte Negro, RO, Brazil.

(4) Campus Centro Oeste, Universidade Federal de São João del Rei, Divinópolis, MG, Brazil.

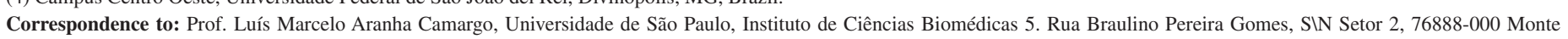
Negro, RO, Brasil. 


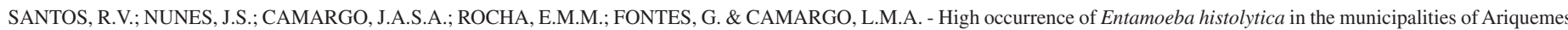
and Monte Negro, State of Rondônia, Western Amazonia, Brazil. Rev. Inst. Med. Trop. Sao Paulo, 55(3): 193-6, 2013.
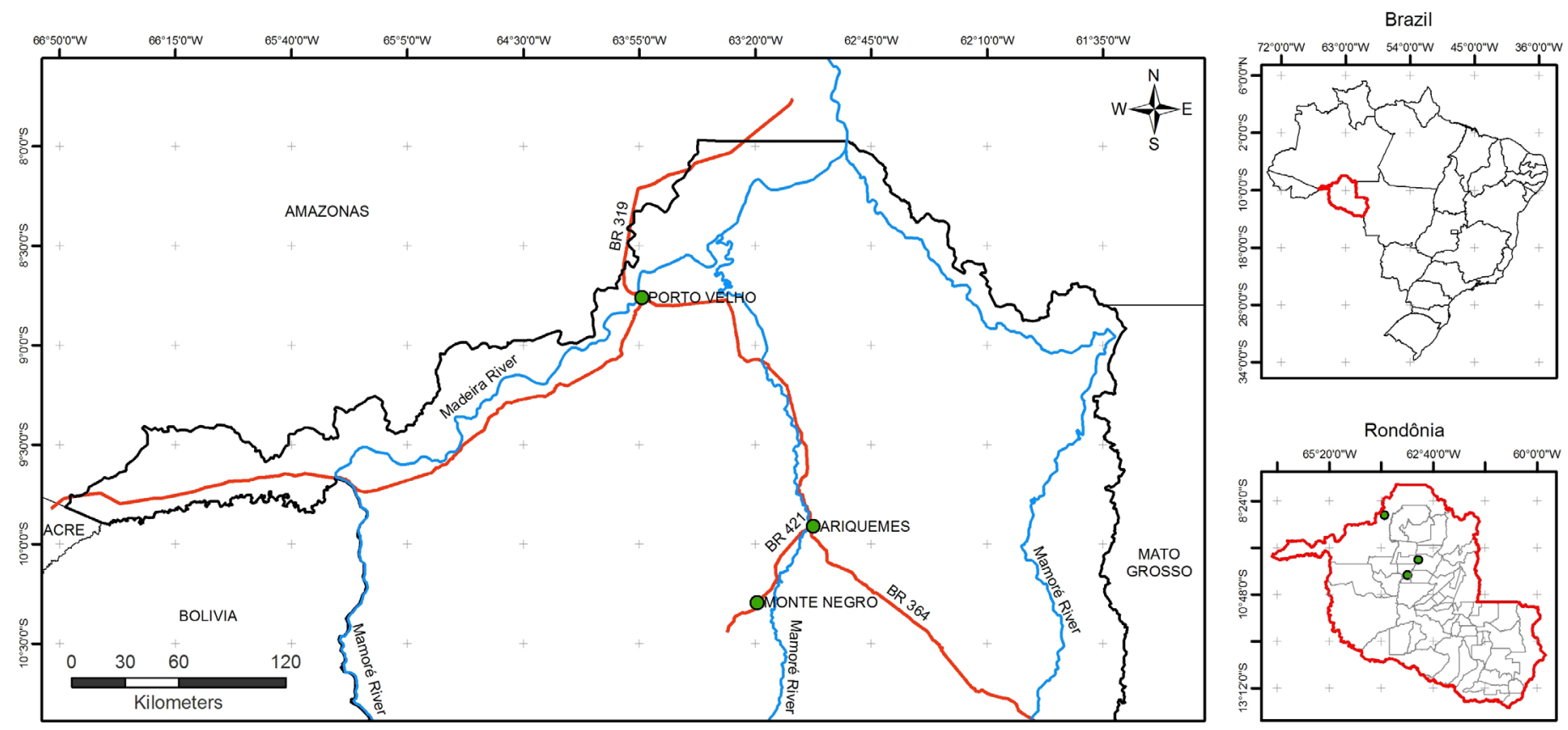

Fig. 1 - Location of Ariquemes and Monte Negro municipalities, State of Rondônia, Western Amazônia, Brazil.

Stool antigen detection is a practical, sensitive and specific method to detect $E$. histolytica infections ${ }^{5}$. In this investigation positive samples for cysts of the E. histolytica/E. dispar complex were subjected to the specific diagnosis for amoebiasis by antigen detection using an ELISA based kit (TechLab E. histolytica II test/TechLab Inc., Blacksburg, VA) according to the manufacturer's instructions. The optical densities (OD) were read at $450 \mathrm{~nm}$ with a spectronic ELISA reader (model TP - Reader, Thermo Plate Devices, China), and a sample was positive if the difference of OD between the test and the negative control was $>0.05$. This technique is designed to detect $E$. histolytica antigens specifically, and not the closely related nonpathogenic E. dispar ${ }^{5,6}$.

Statistical analysis: The results of this study were analyzed using the Epi-Info software, version 3.5.1. The chi-square test was used to compare the data obtained in the two populations. Differences were considered significant in the case of a $p$ value less than 0.05 .

\section{RESULTS}

Coproparasitologic tests by optical microscopy were conducted in a total of 216 stool samples from people living in urban areas, $42.3 \%$ of them were male and $57.7 \%$ female, aged 0 to 75 years. The mean age of the 82 participants from Ariquemes was $17.7 \pm 17.6$ years, and that of the 134 subjects from Monte Negro was $22.3 \pm 17.8$ years.

In Ariquemes 61\% (50/82) of individuals were found infected with E. histolyticalE.dispar, and $44 \%(59 / 134)$ of positive exams for the Entamoeba complex were observed in Monte Negro, with a significant difference in the occurrence of infection between the two populations $\left[p<0.05 ; \chi^{2}=5.2 ;\right.$ odds ratio $\left.2.0(1.1-3.6)\right]$.

The 109 stool specimens showing E. histolytica/E.dispar cysts were analyzed by ELISA for specific diagnosis of E. histolytica, and 56 of them tested positive for the E. histolytica antigen. Considering the total number of stool samples examined (216), the detection rates of amoebiasis were $36.6 \%$ (30/82) and 19.4\% (26/134) for Ariquemes and Monte Negro, respectively. The occurrence rate of amoebiasis was significantly higher in Ariquemes than in Monte Negro $\left[p<0.05 ; \chi^{2}=7.8\right.$; odds ratio $=2.4$ $(1.2$ - 4.7)]. Symptoms commonly associated to amoebiasis were not reported in the studied population.

\section{DISCUSSION}

Few studies have addressed the epidemiology of E. histolytica in Brazil, because most of the existing research used methods which were incapable of distinguishing between the two morphologically identical Entamoeba species (E. dispar and E. histolytica). The results of the present investigation are the first to provide an estimate of the occurrence of amoebiasis among residents of the state of Rondônia.

According to previous epidemiological studies, the rates of $E$. histolytica/E. dispar obtained by optical microscopy in Manaus (state of Amazonas) and Belém (state of Pará), both in the northern region of Brazil, were $21.5 \%$ and $24.8 \%$ respectively ${ }^{1,13}$. These findings are lower than those obtained in Ariquemes 61\% (50/82) and Monte Negro 44\% (59/134).

ORLANDI et al. ${ }^{10,11}$ investigated the etiology of acute diarrheas in infants in Porto Velho, the capital of the state of Rondônia, and found rotavirus as the major etiological agent associated with the disease. However, mixed infections were frequent, associating rotavirus, enteropathogenic Escherichia coli and Salmonella sp with cysts of E. histolytica/E. dispar and Giardia intestinalis.

The E. histolytica antigen detection rate of stool samples was $36.6 \%$ (30/82) from Ariquemes, and 19.4\% (26/134) from fecal specimens from 


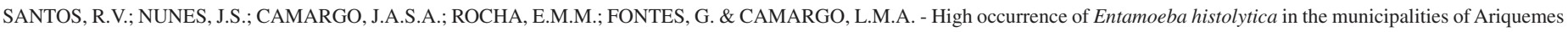
and Monte Negro, State of Rondônia, Western Amazonia, Brazil. Rev. Inst. Med. Trop. Sao Paulo, 55(3): 193-6, 2013.

Monte Negro. The highest prevalence reported in Brazil was in Belém (state of Pará) with $29.3 \%$, which is lower than that found in the city of Ariquemes. The high occurrence of E. histolytica in both cities studied can be attributed to low socio-economic profiles and sanitation conditions, which favor the dissemination of the parasite. It was shown that Rondônia municipalities present the highest rates of Diseases Related to Inadequate Environmental Sanitation (DRIES) in Brazil ${ }^{4}$.

The present epidemiological status of amoebiasis in some countries remains unclear because most of the surveys are based only on the microscopic examination of stool samples, unable to distinguish between $E$. histolytica and E. dispar infections ${ }^{14}$. However, higher prevalence rates are generally observed in areas with precarious environmental sanitation and a lower socioeconomic status. A study conducted in rural villages of Malaysia, using the PCR technique, revealed a higher prevalence of E. histolytica infections (75.0\%) when compared to E. dispar (30.8\%) and E. moshkovskii $(5.8 \%)$ rates $^{8}$. The percentage totals add up to more than $100 \%$ because mixed infections with E. histolytica and E. dispar were found in $11.5 \%$ of the samples. The investigation of Entamoeba infections in a rural Mexican community also found that E. histolytica $(13.8 \%)$ was more prevalent than E. dispar $(9.6 \%)^{12}$.

Due to the high frequency of E. histolytica infected residents diagnosed in Ariquemes and Monte Negro, and the unavailability in local clinics of a test to distinguish between the two Entamoeba species, physicians should consider treating E. histolytica/E.dispar infections despite the recommendation of the $\mathrm{WHO}^{9,15}$ to use ELISA and/or PCR to diagnose specific infections by $E$. histolytica.

\section{CONCLUSION}

The current results point out the need to expand population access to sanitation facilities and a safe water supply, which are critical to reducing Entamoeba transmission. Furthermore, it is necessary to establish a cheap test for the specific diagnosis of amoebiasis caused by E. histolytica and make it available in public laboratories.

\section{RESUMO}

\section{Alta ocorrência de Entamoeba histolytica nos municípios de Ariquemes e Monte Negro, estado de Rondônia, Amazônia Ocidental, Brasil}

Introdução: Infecções por Entamoeba histolytica foram investigadas em moradores dos municípios de Ariquemes e Monte Negro, Rondônia, Brasil. Métodos: Amostras de fezes de 216 indivíduos foram processadas por microscopia óptica para detecção de cistos do complexo E. histolytica/E. dispar, seguido pelo método de imunoensaio utilizando kit de ensaio imunoenzimático para detecção específica de antígeno de E. histolytica. Resultados: Cistos de E. histolytica/E. dispar estavam presentes em $61 \%$ e $44 \%$ das amostras de Ariquemes e Monte Negro, respectivamente com diferença significativa na ocorrência da infecção entre as duas populações $\left[p<0,05 ; \chi^{2}=5,2\right.$; Odds relativa $=2,0(1,1-3,6)]$. A taxa de detecção de antígenos de $E$. histolytica nas amostras provenientes de Ariquemes foi de $36,6 \%$ e de $19,41 \%$ nas amostras de Monte Negro, sendo a ocorrência de amebíase significativamente maior na população de Ariquemes $\left[p<0,05 ; \chi^{2}=7,8\right.$;
Odds relativa $=2,4(1,2-4,7)]$. Discussão: A elevada frequência da infecção por E. histolytica em residentes na região, bem como a indisponibilidade de avaliação clínica por testes específicos para distinção entre as duas espécies de Entamoeba, deve promover uma reflexão sobre o tratamento de infecções pelo complexo $E$. histolytica/E. dispar. Conclusão: Nas populações avaliadas foram detectadas elevadas ocorrências de E. histolytica.

\section{ACKNOWLEDGMENTS}

We thank the inhabitants of Ariquemes and Monte Negro, state of Rondônia, and Marcelo Zagonel from the Instituto Nacional de Genética Médica Populacional (INAGEMP) of the Conselho Nacional de Desenvolvimento Científico e Tecnológico (CNPq), for the map.

\section{REFERENCES}

1. Benetton ML, Gonçalves AV, Meneghini ME, Silva EF, Carneiro M. Risk factors for infection by the Entamoeba histolytica/E. dispar complex: an epidemiological study conducted in outpatient clinics in the city of Manaus, Amazon region, Brazil. Trans R Soc Trop Med Hyg. 2005;99:532-40.

2. Braga LL, Gomes ML, Silva MW, Paiva C, Sales A, Mann BJ. Entamoeba histolytica and Entamoeba dispar infections as detected by monoclonal antibody in an urban slum in Fortaleza, Northeastern Brazil. Rev Soc Bras Med Trop. 2001;34:467-71.

3. Chacín-Bonilla L. Microscopic diagnosis of amebiasis: an obsolete method but necessary in the developing world. Invest Clin. 2011;52:291-94.

4. Fonseca FR, Vasconcelos $\mathrm{CH}$. Análise especial das doenças relacionadas ao saneamento ambiental inadequado no Brasil. Cad. Saúde Colet (Rio J). 2011;19:44853.

5. Haque R, Ali IKM, Akther S, Petri WA Jr. Comparison of PCR, isoenzyme analysis, and antigen detection for diagnosis of Entamoeba histolytica infection. J Clin Microbiol. 1998;36:449-52.

6. Haque R, Kress K, Wood S, Jackson TF, Lyerly D, Wilkins T, et al. Diagnosis of pathogenic Entamoeba histolytica infection using a stool ELISA base on monoclonal antibodies to the galactose-specific adhesin. J Infect Dis. 1993;167:247-9.

7. Hoffman WA, Pons JA, Janer JL. The sedimentation concentration method in Schistosomiasis mansoni. Puerto Rico J Publ Health Trop Med. 1934;9:283-98.

8. Ngui R, Angal L, Fakhrurrazi AS, Lian YL, Ling LY, Ibrahim J, et al. Differentiating Entamoeba histolytica, Entamoeba dispar and Entamoeba moshkovskii using nested polymerase chain reaction (PCR) in rural communities in Malaysia. Parasit Vectors. 2012;5:187.

9. Organizacion Mundial de la Salud/Organizacion Panamerica de la Salud/ Organizacion de las Naciones Unidas para la Educacion, la Ciencia y la Cultura. Consulta con expertos en amibiasis. Ciudad de México, México, del 28 al 29 de enero de 1997. OPS Bol Epidem.1997;18:13-4.

10. Orlandi PP, Magalhães GF, Matos NB, Silva T, Penatti M, Nogueira PA, et al. Etiology of diarrheal infections in children of Porto Velho (Rondonia, Western Amazon region, Brazil). Braz J Med Biol Res. 2006;39:507-17.

11. Orlandi PP, Silva T, Magalhães GF, Alves F, de Almeida Cunha RP, Durlacher R, Silva LHP. Enteropathogens associated with diarrheal disease in infants of poor urban areas of Porto Velho, Rondônia: a preliminary study. Mem Inst Oswaldo Cruz. 2001;96:621-5.

12. Ramos F, Morán P, González E, Garcia G, Ramiro M, Gómez A, et al. Entamoeba histolytica and Entamoeba dispar: prevalence infection in a rural Mexican community. Exp Parasitol. 2005;110:327-30. 
SANTOS, R.V.; NUNES, J.S.; CAMARGO, J.A.S.A.; ROCHA, E.M.M.; FONTES, G. \& CAMARGO, L.M.A. - High occurrence of Entamoeba histolytica in the municipalities of Ariquemes and Monte Negro, State of Rondônia, Western Amazonia, Brazil. Rev. Inst. Med. Trop. Sao Paulo, 55(3): 193-6, 2013.

13. Silva MCM, Monteiro CSP, Araújo BAV, Silva JV, Póvoa MM. Determinação da infecção por Entamoeba histolytica em residentes da área metropolitana de Belém, Pará, Brasil, utilizando ensaio imunoenzimático (ELISA) para detecção de antígenos. Cad Saúde Pública. 2005;21:969-73.

15. World Health Organization. Amoebiasis. Weekly Epidemiol Rec. 1997;72:97-100.

Received: 30 July 2012

Accepted: 16 October 2012

14. Tanyuksel M, Petri WA Jr. Laboratory diagnosis of amebiases. J Clin Microbiol. 2003;16:713-29. 